\title{
Fair labor practices in values-based agrifood supply chains?
}

\author{
Larry L. Burmeister ${ }^{a *}$ \\ Ohio University \\ Keiko Tanaka ${ }^{b}$ \\ University of Kentucky
}

Submitted November 7, 2016 / Revised February 24 and June 24, 2017 / Accepted June 25, 2017 /

Published online September 6, 2017

Citation: Burmeister, L. L., \& Tanaka, K. (2017). Fair labor practices in values-based agrifood

supply chains? Journal of Agriculture, Food Systems, and Community Development, 7(3), 17-22.

http://dx.doi.org/10.5304/jafscd.2017.073.019

Copyright (C) 2017 by New Leaf Associates, Inc.

\begin{abstract}
This research commentary reviews our exploratory study of the incorporation of fair labor practices into the business models of values-based agrifood supply chains (VBSCs) studied in the USDAsponsored "agriculture-of-the-middle" (AOTM) regional research project. We examined what the certification affiliations of AOTM enterprises signaled about their values priorities as described in AOTM case study documents and in the enterprises' website advertising outreach. While we found weak evidence for prioritization of the fair labor practices value in these case study materials, our analysis suggests that characteristics of VBSC lead enterprises-whether the VBSCs are

a $*$ Corresponding author: Larry L. Burmeister, Department of Sociology \& Anthropology; 121 Bentley Annex; Ohio University; Athens, OH 45701 USA; burmeist@,ohio.edu

b Keiko Tanaka, Department of Community \& Leadership Development; 704 Garrigus Building; University of Kentucky; Lexington, KY 40546-0215 USA; keiko.tanaka@uky.edu
\end{abstract}

producer-, consumer-, or aggregator-drivenprovide a promising focus for future research into possibilities for fair labor practices in these types of alternative agrifood enterprises. In an effort to advance research on this important but relatively neglected topic in the alternative agriculture literature, we note the need to develop effective, ethical research strategies to investigate sensitive labor issues in alternative agrifoood supply chains and to identify labor-intensive VBSCs as future case study targets.

\section{Keywords}

Alternative Agriculture; Agriculture of the Middle; Certification; Fair Trade; Labor; Social Justice; Values-Based Agrifood Supply Chains

\section{Commentary}

The Journal of Agriculture, Food Systems, and Community Development's (JAFSCD's) recent issue on the topic of "Labor in the food system, from farm to 
table" (volume 6, issue 2, winter 2015-2016) provides a fortuitous backdrop for our research commentary. In an effort to explore possibilities for fair labor practices in the contemporary American agrifood system, we look toward valuesbased agrifood supply chains (VBSCs) as potential sites of positive development. VBSCs have emerged as entrepreneurial efforts among farmers and other supporters (wholesale aggregators, consumer cooperatives, etc.) to develop and market high-quality products that offer economically viable niches for midsized family farm enterprises (the so-called disappearing middle in American agriculture). These VBSC enterprise strategies are rooted in values prioritized in the alternative agriculture critique of the conventional agrifood system. Examples of VBSC values priorities include unadulterated (reduced chemical and antibiotic input), "natural," or organically produced foodstuffs; environmentally and ecologically sustainable production practices; humane animal treatment; relational buying and selling (where consumers know where their food comes from and how it is produced); and local/regional provenance of foodstuffs with its positive cultural (e.g., place identity), ecological (e.g., limited food miles), and local/regional economic development promotion implications. In one of the foundational statements of VBSC business principles, fair labor practices for workers are also identified as aspirational values (Stevenson \& Pirog, 2008).

As highlighted in the JAFSCD issue referenced above, many farmworkers face work environments characterized by low wages, lack of benefits, dangerous and difficult working conditions, lack of adequate housing, and abusive worker treatment on and off the job (Bon Appétit Management Company Foundation \& United Farm Workers, 2011; Gottlieb \& Joshi, 2010; Liu \& Apollon, 2011). Workers in the processing and food service links in the food chain often suffer similar economic hardships and workplace indignities. The irony of high levels of food insecurity among those who labor to produce, process, prepare, and serve America's food attests to ongoing social justice concerns regarding the labor regime throughout the food chain (Brown \& Getz, 2011; Fox, 2013). Within the food justice movement, fair labor practices (defined as providing living wages, adequate health care benefits, safe working conditions, and guarantees of worker rights to challenge employer abuses) are considered essential attributes of a more socially just alternative food economy (see Gottlieb and Joshi, 2010, and International Labor Organization [ILO], 2017). Yet attempts to create regimes for fair labor practice have emerged more prominently in fair trade arrangements negotiated within global agrifood supply chains. As Allen (2004) and Brown and Getz (2011) have emphasized, the alternative agriculture movement in the United States has, for the most part, elided labor issues, creating a major social gap in its agrifood system transformation efforts.

Have concerns from the fair trade movement about just labor practices influenced VBSC business models? This question motivated us to review case studies of exemplary VBSC enterprises documented in the USDA agriculture-of-themiddle regional research project (see http://www.agofthemiddle.org). While much of the AOTM case study literature highlights the collective responsibility of supply chain actors to implement and maintain values-based standards, third-party certification is advocated as a quality assurance mechanism (Stevenson \& Pirog, 2008). As Brown and Getz (2008) point out, certification systems have proliferated in the past decade as mechanisms for strengthening transparency in fair trade and other alternative agricultural product chains that claim adherence to particular product standards (e.g., quality, environmental sustainability, social accountability, etc.). Certification systems may help identify and resolve internal difficulties in realizing values-based production objectives. In addition, certification represents an significant marketing tool for enterprises producing for value-added market niches, as it provides important assurance information to consumers that the product conforms to advertised standards. Examining certification affiliations of the AOTM cases, we surmised, might signal which values priorities, including fair labor practices, appear most prominently in AOTM VBSC business models.

In our review of the eight AOTM case studies, we found that seven affiliated with one or more certification agents. While four of the VBSCs had 
certification agency affiliations that reflect fair trade movement concerns about labor conditions in the food chain, more prominent were affiliations that focused on assurances of "good food quality" (organic, non-GMO) and "environmentally friendly" production practices that are emphasized in the alternative agriculture movement. Certification affiliations, when emphasized in AOTM VBSC branding narratives, seemed primarily aimed at packaging values that appeal to food-conscious consumers interested in the taste, health, and ecological attributes of their food purchases. Fair labor practice values were not prominent in AOTM VBSC case study descriptions of business practices or in their advertising campaigns.

To the extent that mention of fair labor practices did surface in case study documents, our analysis points to the VBSC lead enterprise type as a heuristic explanatory factor. AOTM supply chains were created by lead enterprises such as producer cooperatives, consumer cooperatives, and wholesale intermediaries in order to effect a stable farm-to-market flow of values-based products. Our typology of lead enterprise structure borrows Gereffi and Korzeniewicz's (1994) seminal distinction between producer- and consumer-driven supply chains. We expand their typology by adding a third "aggregator-driven" supply chain possibility. These three distinctive types of lead enterprises are situated in different power positions vis-à-vis supply chain partners, with important implications for integrating fair labor practices as prominent values in their supply chain operations.

Take the case of producer-driven supply chains, the most frequent type in the AOTM case study portfolio. Farmers organized these supply chains with the explicit goal of developing premium quality products (that they project will command a price premium) for discerning consumers seeking alternatives to conventionally produced foods. Economically viable values-based production requires supply-chain entrepreneurship, i.e., the forging of alliances with downstream partners who maintain lead enterprise product quality standards in their operations. These partners often have powerful positions in the supply chain, as they fill essential nodes necessary for the lead producer-driven enterprise to process and sell a marketable product. These are often marriages of convenience with more conventional agrifood system partners, in the sense that AOTM enterprises do not have the resources to build from the ground up entire supply chains in their values-based image. If producer-driven lead enterprises were to incorporate fair labor practices into their values-based models (for instance, by committing to living wage policies for their employees), critical supply chain partners might not be able to implement them due to company-specific economic or other constraints. Conversely, our case study review suggested that a powerful downstream retail partner (e.g., a major buyer) with fair labor practice values could exert considerable upstream pressure among producerdriven enterprises for compliance with their values.

In contrast to the producer-driven scenario, we found that aggregator-led VBSCs are in a position to implement their values proactively, especially in the upstream producer end of the supply chain. Aggregators can provide robust market channels for premium-priced, high-quality products (with fair labor practices as one of the marketed quality attributes) if producers can meet quality standards. Aggregators may offer farmers a cost-plus price point that ensures economic viability for smaller, midscale operators.

Similarly, consumer-driven supply chains, such as those organized by consumer cooperatives, are in a favorable power position to influence upstream supply chain partners to meet the valuesbased product preferences of cooperative members. The very limited survey research on consumer rationales for purchasing value-based food products, such as organics, highlights health and environment concerns as paramount, with little evidence that fair labor practices in the food chain figure in purchasing decisions. Looking forward, the leadership of consumer cooperatives could be an important factor in educating their members about the labor justice component of fair trade principles. Perhaps the increased attention to inequality in American society provides an entry point for enhanced consumer cooperative dialogue about food justice concerns in their sourcing policies.

It is important to remember that VBSCs are embedded in a larger, competitive food market 
structure. Stark economic realities make it difficult for VBSCs to prioritize fair labor practices in their business models, especially when they are uncertain about whether consumers will pay extra for a product with a food justice label. As Martin (2013) notes, labor is one of the most controllable costs in production agriculture. The omission of farmworkers from protections encoded in the National Labor Relations Act (the Wagner Act) and legislation on fair labor standards means that VBSCs implementing fair labor practices would operate on an uneven playing field with competitors. Conventional production agriculture's reliance on undocumented immigrant farmworkers, who are often subject to exploitative treatment due to their problematic legal status (see Gray, 2013, and Holmes, 2013), enhances labor cost disadvantages for VBSCs adhering to fair labor standards.

As emphasized in the literature, in fact, VBSCs are often created through hybrid (Bloom \& Hinrichs, 2011) enterprise coalitions. Our AOTM case study review reveals that values-based agrifood businesses often partner strategically with enterprises that are part of the conventional agrifood system in order to process, distribute, and sell their product. In effect, they are often integrated into downstream components of the larger conventional agrifood system within which they lack the countervailing market power to impose their fair labor practice values on partners. This structural reality constrains lead enterprises' valuesbased attempts to implement fair labor practices throughout the supply chain.

Critics of the alternative agriculture movement argue that the economic and supply chain power imbalance constraints noted above may reflect only one (the materialistic) side of the weak adherence to fair labor practice values we have noted in the AOTM VBSC case studies. Allen (2004), for example, argues that attention to social justice issues for agrifood system workers is muted due to ideological biases within the alternative agriculture movement. These biases are particularly likely to surface in the values priorities of producer-driven (farmer-organized) VBSC supply chains. Allen identifies conservative biases within the movement-agrarianism and farm-centrism, individualism and self-reliance, economic liberalism, ideologies of class and merit, and fetishization of the environment - as key ideational underpinnings that mitigate against the incorporation of fair labor arrangements into movement practice (Allen, 2004). The ideological barriers to implementing fair labor practices, even within fair trade regimes that explicitly proclaim this value, are noted in a recent review of the fair trade movement (Terstappen, Hanson, \& McLaughlin, 2013). This review acknowledges that the international fair trade movement, like the alternative agrifood movement in the U.S., is decidedly farmer-centric in terms of values priorities. The focus on farmers' economic welfare and the the assumption that most farm labor is provided by family members divert attention from conditions for hired labor in fair trade production.

As argued by Alkon and Agyemon (2011), certain key components of the alternative agriculture vision-food localism, fair trade, slow food, etc.-are socially exclusionary. Guthman (2011) sees decided class and racial biases in the social construction of vision authority. DuPuis, Harrison, and Goodman (2011) call for more focus by the movement on the processes through which visions are constructed, a reflexive, democratizing approach to expanding the food justice dialogue to include eaters and workers who have heretofore been left out of the defining process. Initial attempts to initiate this dialogue are evident in the work of organizations like the Domestic Fair Trade Association (http:/ / www.thedfta.org), a diverse, membership-based group of actors (growers, farmworkers, consumer cooperatives, food service workers, NGOs, academics, etc.) working to promote a fair trade regime in the American agrifood system.

Further exploration of the materialistic and ideological constraints to incorporating fair labor practices into values-based supply chains requires more systematic efforts to design studies to probe these concerns. A major limitation of the AOTM VBSC case studies was the lack of directed inquiries regarding labor in the interview protocol. Case study researchers used open-ended interview techniques to explore the range of values priorities in VBSC business models as articulated by key informants who had been instrumental in the 
founding of the businesses. It is possible that key informants were much less willing to talk about sensitive labor issues that highlighted contradictions in business practices designed to support the economic welfare of all supply chain actors. After all, in the American political economy context, labor issues within the agrifood system remain contentious and largely unresolved (Martin, 2013). One can envision potential legal ramifications if problematic labor issues (e.g., undocumented workers) are revealed in research reports. Unless a labor dispute has already become public, information about business practices relating to labor issues is unlikely to surface in the type of research instrument employed in the AOTM VBSC project. Furthermore, the vulnerability of many VBSC enterprises in the dynamic, competitive American agrifood system raises ethical questions about how to study problematic labor aspects of VBSCs without damaging their hard-won progressive reputations.
Our aim in this commentary is to spark discussion of how to bring labor into the analysis of ongoing efforts to create a more just, sustainable agrifood system. Among producers of values-based products, these is much uncertainty about securing the labor necessary to sustain their production operations. Assurances of fair labor conditions may offer an important strategy for alternative agrifood enterprises to secure the labor they need. We need case studies of VBSCs that have successfully integrated fair labor practices into their business operations. One possibility is that some of the AOTM VBSC cases or other cases mentioned in attempts to document VBSC development (Lerman, 2012; Lerman, Feenstra, \& Visher, 2012) have made progress in instituting fair labor practices. A re-study of the more labor-intensive VBSC enterprises with a focus on enterprise approaches to dealing with labor supply issues seems warranted.

\section{References}

Alkon, A. H., \& Agyeman, J. (Eds.). (2011). Cultivating food justice: Race, class, and sustainability. Cambridge, Massachusetts: MIT Press.

Allen, P. (2004). Together at the table: Sustainability and sustenance in the American agrifood system. University Park: The Pennsylvania State University Press.

Bon Appétit Management Company Foundation \& United Farm Workers. (2011). Inventory of farmworker issues and protections in the United States. Retrieved from https://www.oxfamamerica.org/publications/inventory-offarmworker-issues-and-protections-in-the-united-states/?searchterm=farmworker $\% 20$ inventory

Bloom, J. D., \& Hinrichs, C. C. (2011). Informal and formal mechanisms of coordination in hybrid food value chains. Journal of Agriculture, Food Systems, and Community Development, 1(4), 143-156. https://dx.doi.org/10.5304/jafscd.2011.014.016

Brown, S., \& Getz, C. (2011). Farmworker insecurity and the production of hunger in California. In A. H. Alkon \& J. Agyeman (Eds.), Cultivating food justice: Race, class, and sustainability (pp. 121-146). Cambridge, Massachusetts: The MIT Press.

Dupuis, E., Harrison, J., \& Goodman, D. (2011). Just food? In A. H. Alkon \& J. Agyeman (Eds.), Cultivating food justice: Race, class, and sustainability (pp. 283-307). Cambridge, Massachusetts: The MIT Press.

Fox, E. J. (2013, October 23). McDonald's helps workers get food stamps [CNN Money blog post]. Retrieved from http://money.cnn.com/2013/10/23/news/companies/mcdonalds-help-line-workers/index.html

Gereffi, G., \& Korzeniewicz, M. (Eds.). (1994). Commodity chains and global capitalism. Westport, Connecticut: Greenwood Press.

Gottlieb, R., \& Joshi, A. (2010). Food justice. Cambridge, Massachusetts: The MIT Press.

Gray, M. (2014). Labor and the locavore: The making of a comprehensive food etbic. Berkeley: University of California Press.

Guthman, J. (2011). "If they only knew": The unbearable whiteness of alternative food. In A. H. Alkon \& J. Agyeman (Eds.), Cultivating food justice: Race, class, and sustainability (pp. 263-281). Cambridge, Massachusetts: The MIT Press.

Holmes, S. M. (2013). Fresh fruit, broken bodies: Migrant farmworkers in the United States. Berkeley and Los Angeles: University of California Press. 
International Labor Organization [ILO]. (2017). Decent work and the 2030 Agenda for sustainable development. Geneva: Author. Retrieved from http://www.ilo.org/global/topics/sdg-2030/lang--en/index.htm

Lerman, T. (2012). A review of scholarly literature on values-based supply chains. Davis, California: Sustainable Agriculture Research and Education Program, Agricultural Sustainability Institute, University of California, Davis. Retrieved from http://asi.ucdavis.edu/programs/sarep/publications/food-and-society/foodhubsandvaluesbasedsupply chains-review-2012.pdf

Lerman, T., Feenstra, G., \& Visher, D. (2012). A practitioner's guide to resources and publications on food bubs and values-based supply chains: A literature review. Sustainable Agriculture Research and Education Program, Agricultural Sustainability Institute, University of California, Davis. Retrieved from http://asi.ucdavis.edu/programs/sarep/publications/ food-and-society/foodhubsandvaluesbasedsupplychains-litreview-2012.pdf

Liu, Y. Y., \& Apollon, D. (2011). The color of food. Applied Research Center (now Race Forward). Retrieved from https://www.raceforward.org/sites/default/files/downloads/food justice 021611 F.pdf

Martin, P. L. (2013). Migration and US agricultural competitiveness. Migration Letters, 10(2), 159-179. Retrieved from http://www.tplondon.com/journal/index.php/ml/article/view/4/20

Stevenson, G. W., \& Pirog, R. (2008). Values-based supply chains: Strategies for agrifood enterprises of the middle. In T. A. Lyson, G. W. Stevenson, \& R. Welsh (Eds.), Food and the mid-level farm: Renewing an agriculture of the middle (pp. 119143). Cambridge, Massachusetts: The MIT Press. https://dx.doi.org/10.7551/mitpress/9780262122993.003.0007

Terstappen, V., Hanson, L., \& McLaughlin, D. (2013). Gender, health, labor, and inequities: A review of the fair and alternative trade literature. Agriculture and Human Values, 30(1), 21-39. https://dx.doi.org/10.1007/s10460-012$\underline{9377-7}$ 